\title{
INDEPENDENSI PENILAIAN AMDAL SEBAGAI WUJ UD PERLINDUNGAN TERHADAP LINGKUNGAN HIDUP
}

\author{
Ivan Wagner ${ }^{1 *}$, Suteki² \\ 1Program Studi Magister Ilmu Hukum, Fakultas Hukum, Universitas Diponegoro \\ 2Fakultas Hukum, Universitas Diponegoro \\ iwagnerious@gmail.com
}

\begin{abstract}
Environmental Impact Analysis (EIA) has become an instrument of environmental protection in Act Number 32 of 2009 on Environmental Protection and Management. Amdal is always associated with an independent, scientific, objective, and even neutral. Such matters must still be questioned regarding the content of the core values of life that are often ignored, especially because they still cause conflict, and even have an impact on the destruction of the environment and casualties. Based on the foregoing, the principal issues raised in this thesis are: First, why is the EIA assessment conducted independently?; and Second, what is the ideal concept that can be given for the conception of planning in the context of Environmental Protection? The study uses a stand point of critical theory et al paradigm and socio-legal perspective. The research concludes that the independence of the EIA assessment which was originally intended as an effort to eliminate the entry of political interests and other particular interests from environmental licensing officials, is merely a "myth" and "illusion". this certainly gives an opportunity to be used as a normative justification tool for independence, objectivity and expertise, by utilizing the literal and scalar dichotomy between the words depend/be a part (dependent), with not depend/separate (independence), to cover up the role of power. Then it is necessary to formulate a conception of planning and environmental impact assessment that carries a relational approach, based on an ethics of care, and the centrality of the people's own needs which fosters independence/autonomy rather than damaging the core values of life.
\end{abstract}

\section{Keywords: Environmental Impact Assessments; Environmental Protection; Independence; North Kendeng Highlands; Critical Theory; Relational Approach.}

\begin{abstract}
ABSTRAK
Analisis Mengenai Dampak Lingkungan Hidup (Amdal) telah menjadi instrumen perlindungan lingkungan hidup dalam UU No 32 Tahun 2009. Amdal selalu dikaitkan dengan sifat yang independen, ilmiah, objektif, bahkan netral. Hal demikian wajib dipertanyakan berkaitan dengan kandungan nilai-nilai inti kehidupan yang sering diabaikan, terutama karena menyebabkan konflik, bahkan membawa dampak rusaknya lingkungan hidup dan jatuhnya korban. Berdasarkan hal tersebut di atas, permasalahan yang diangkat adalah: Pertama, Mengapa penilaian Amdal perlu dilakukan secara independen?; dan Kedua, Bagaimana konsep ideal perencanaan berbasis independensi dalam rangka perlindungan terhadap lingkungan hidup? Penelitian menggunakan stand point paradigma critical theory et.al dan perspektif sosio-legal. Penelitian menghasilkan kesimpulan bahwa independensi penilaian Amdal yang semula dimaksudkan sebagai upaya menghilangkan masuknya kepentingan politik dan kepentingan partikular lainnya dari pejabat pemberi izin lingkungan, merupakan sebatas "mitos" dan "ilusi". Hal demikian memberi peluang untuk digunakan sebagai alat justifikasi normatif terhadap independensi, objektivitas dan kepakaran, dengan memanfaatkan dikotomi harfiah dan skalar antara kata tergantung/menjadi bagian (dependence) dengan tidak bergantung/terpisah
\end{abstract}

\footnotetext{
${ }^{*}$ Corresponding Author
} 
(independence), untuk menutup-nutupi peran kekuasaan. Kemudian perlu dirumuskan konsepsi perencanaan dan penilaian dampak lingkungan yang mengusung pendekatan relasional, berbasiskan etika kepedulian, dan sentralitas dari kebutuhan rakyat itu sendiri yang menumbuhkan independensi/otonomi dan bukannya merusak nilai-nilai inti kehidupan.

\section{Kata Kunci: Amdal; Perlindungan Lingkungan Hidup; Independensi; Pegunungan Kendeng Utara; Critical Theory, Pendekatan Relasional.}

\section{A. PENDAhULUAN}

Indonesia telah melakukan empat kali amademen konstitusi, dimana dalam batang tubuh UUD 1945 ditambahkan ketentuan mengenai hak asasi manusia, yang salah satunya ialah hak atas lingkungan yang baik dan sehat. Undang-Undang Nomor 32 Tahun 2009 tentang Perlindungan dan Pengelolaan Lingkungan Hidup (UU 32/2009) mendapat dasar konstitusional utamanya dari ketentuan hak atas lingkungan yang baik dan sehat tersebut. UU 32/2009 lahir setelah dilakukan evaluasi yang salah satunya ialah mengenai Analisis Mengenai Dampak Lingkungan (Amdal) yang sebelumnya telah diatur dalam undang-undang lingkungan hidup sebelum UU 32/2009 yaitu UndangUndang Nomor 4 Tahun 1982 tentang Ketentuan Pokok Pengelolaan Lingkungan Hidup (UU 4/1982), maupun Undang-Undang Nomor 23 Tahun 1997 tentang Pengelolaan Lingkungan Hidup (UU 23/1997).

Konsep Amdal dalam UU 32/2009 merupakan bagian integral dari konsep perlindungan lingkungan hidup. Dalam konsep itu, membicarakan konsep partisipasi masyarakat dalam bingkai demokrasi lingkungan, penguatan melalui desentralisasi kewenangan kelembagaan institusi lingkungan hidup khususnya dalam penilaian Amdal, bahkan pengaturan sertifikasi pembuat Amdal untuk menunjang kualitas Amdal. Konsepsi Amdal juga dibuat berkaitan erat dengan penerbitan Izin Lingkungan dan Izin Usaha dan/atau Kegiatan. Namun, setelah sepuluh tahun berlakunya UU $32 / 2009$, pelaksanaan aturan bahkan konsepkonsepnya, dirasa perlu untuk kembali dipertanyakan secara kritis, khususnya mengenai Amdal.

Beberapa tahun belakangan, sistem hukum lingkungan kaitannya dengan berbagai instrumen pencegahan kerusakan lingkungan hidup, antara lain seperti Kajian Lingkungan Hidup Strategis (KLHS), Penataan Ruang, Amdal, hingga Izin Lingkungan, menghadapi kasus-kasus yang menyita perhatian publik. Salah satu yang mendapat perhatian besar ialah penolakan penambangan dan pendirian pabrik semen di Pegunungan Kendeng Utara, Jawa Tengah. Yang terus menjadi sorotan, ialah dua kasus terpisah namun masih dalam konteks dan ekosistem yang sama, yaitu kasus yang melibatkan rencana usaha PT. Semen Indonesia (Persero) Tbk (SMGR) di Kabupaten Rembang, dan yang melibatkan PT. Sahabat Mulia Sakti yang merupakan anak perusahaan PT. Indocement Tunggal Prakarsa Tbk (INTP) di Kabupaten Pati. 
Jurnal Pembangunan Hukum Indonesia

Volume 1, Nomor 3, Tahun 2019
Program Studi Magister Ilmu Hukum Fakultas Hukum Universitas Diponegoro
Montesquieu pernah menyampaikan, "kita harus mengakui bahwa relasi keadilan sudah ada terlebih dulu sebelum ada hukum positif, yang digunakan untuk menetapkan relasi-relasi tersebut" (Montesquieu, 2015). Berkaitan dengan konteks relasi tersebut, Nedelsky merumuskan konsep diri, otonomi, dan hukum yang direkonstruksi sehingga (bersifat) "relasional". Karena bentuk otonomi yang dikonstruksinya adalah relasional, maka bentuknya adalah berlawanan dari konsep otonomi yang bersifat keterpisahan (separation) (Nedelsky, 2011). Independensi individualistis dalam bentuk ekstremnya menyiratkan pemisahan dari dengan yang lain (Plath, 2009). Hal demikian berbeda dari konsepsi dominan seperti konsep pemisahan kekuasaan (separation of power). Independensi penting, dengan memahami konteksnya secara nonharfiah sama inklusifnya dengan konseptualisasi Nedelsky terhadap konsep otonomi relasional (Friedman, 2013). Konsepsi Nedelsky yaitu, bahwa "nilai-nilai inti" kehidupan manusia harus dipahami dengan cara memperhitungkan sentralitas hubungan ini (Nedelsky, 2011).

Konsepsi independensi relasional juga didapat dari pemikiran seorang feminis yaitu Mary Wollstonecraft yang berupaya menggunakan cita-cita mengatasi bentuk-bentuk dominasi sosial dan struktural, serta memotivasi dan mendorong pengembangan cita-cita (Coffee, 2013); (Coffee, 2018); (Mackenzie, 2016); (Halldenius, 2007). Independensi identik dengan kebebasan yang dipahami sebagai ketiadaan kekuasaan sewenang-

wenang, dan ketergantungan menunjukkan perbudakan (Coffee, 2014 Forthcoming). Berkaitan dengan kesetaraan dan kebebasan, Kesetaraan ialah capaian liberal (Nedelsky, 2011), kemudian Unger berpendapat,

"Our chance of rising to a greater life and of achieving a deep freedom is the standard by which should ultimately distinguish between the permissible and the impermissible forms of inequality" (Unger, 2013).

Nedelsky menyampaikan bahwa terdapat dikotomi semisal negara-individu, publik-privat, atau politik-pasar, dan selalu merupakan ilusi dan mitos. Dalam studi hukum kritis dikenal juga sebagai "fundamental contradiction" (Kennedy, 1979). Penyajian kontradiksi mendasar antara "diri sendiri" dan "orang lain" terkait dengan dikotomi lain yang merupakan ekspresi alternatif atau derivasi darinya: "subjectivity" vs "objectivity", "public" dan "privat", "state" dan "civil society" (Tushnet, 1981); (Hunt, 1986). Terhadap objektivisme merumuskan model pencarian melalui sarana doktrin penyimpangan (deviasi), termasuk kritik analitis dan historis terhadap konsepsi hukum yang telah mapan (Unger, 1983). Dikotomi tersebut, sejak awal berfungsi untuk menutupi peran kekuasaan negara di set kedua istilah (Nedelsky, 2011). Dibalik semua doktrin hukum dan sistem hukum, berdiri penilaian politik yang mencerminkan dominasi yang tidak diartikulasikan dari pembuat dan pembentuk hukum (Adamian, 2008)

Mengenai

menyampaikan

$$
\text { kekuasaan, }
$$
bahwa kekuasaan
Foucault adalah 
Jurnal Pembangunan Hukum Indonesia

Volume 1, Nomor 3, Tahun 2019
Program Studi Magister Ilmu Hukum Fakultas Hukum Universitas Diponegoro "serangkaian aksi terhadap aksi-aksi potensial; kekuasaan memancing, merangsang, memudahkan ataupun mempersulit" - kekuasaan adalah "pengaturan perilaku" (conduct of conduct) dan manajemen peluang" (Foucault, 2001); (Death, 2014). Dimana ada kekuasaan, di situ ada perlawanan (Foucault, 1998), fenomena ini adalah "perilaku-tandingan", atau sebuah "perjuangan melawan proses-proses yang diterapkan untuk mengatur orang lain (Foucault, 2007).

Amdal dan proses penilaiannya dipersepsikan ilmiah, objektif, netral dan independen. Apalagi dalam Pasal 30 ayat (2) UU 32/2009, disampaikan:

"Dalam melaksanakan tugasnya, Komisi Penilai Amdal dibantu oleh tim teknis yang terdiri atas pakar independen yang melakukan kajian teknis dan sekretariat yang dibentuk untuk itu".

Namun, dinamika dalam proses Amdal hingga penerbitan izin lingkungan, menyisakan dilema yang besar bagi warga yang bersengketa. Proses Amdal yang berujung pada konsensus layak atau tidak layak lingkungan lebih menampilkan hubungan kekuasaan yang kental dalam pencapaian konsensus. Konsepsi Amdal dan penilaiannya yang dipersepsikan ilmiah, objektif, netral dan secara khusus diperjelas norma UU 32/2009 yaitu independen, layak untuk dipertanyakan. Maka penulis merumuskan masalah sebagai berikut: (1) Mengapa penilaian Analisis Mengenai Dampak Lingkungan dilakukan secara independen?; dan (2) Bagaimana konsep ideal yang dapat diberikan bagi konsepsi perencanaan dalam rangka Perlindungan Lingkungan Hidup?
Dalam Amdal, belum ada jaminan perlindungan bagi masyarakat yang tidak dilibatkan dalam proses penyusunan Amdal, bahkan implikasi dari peraturan perundang-undangan tersebut masih minim dan tidak dilibatkannya masyarakat dalam proses penyusunan Amdal berimplikasi pada dapat diajukannya gugatan ke PTUN (Ciptaningrum, Atikah, \& Fadhilah, 2017). Maka kajian ini penting melihat faktor tentang tidak adanya jaminan yang dimaksud. Mengenai kasus yang sama yaitu di Pegunungan Kendeng Utara, dalam hal proses litigasi, Nugroho mengatakan: Ada pengaruh dari interaksi antara sistem hukum pada cara hakim dalam menilai objek sengketa. "they only used a problematic thinking model" (Nugroho, 2018). Dalam kajian ini, lebih jauh untuk memahami pengaruh interaksi antara sistem hukum dengan masalah yang disengketakan.

Beralih ke perlindungan kawasan karst, bahwa selain karena faktor ekonomi yang mendominasi, faktor dilematis pemerintah dalam menertibkan para penambang semakin menyebabkan regulasi yang ada tidak berjalan secara optimal (Amalia, Samekto, \& Prihatin, 2016). Dalam kajian ini bermaksud sebaliknya, yaitu berusaha memahami posisi dilematis warga terdampak, dan apa regulasi yang memfasilitasinya. Dalam Amdal, Enriquez-deSalamanca menyampaikan: "stakeholders' bias is unavoidable." Selanjutnya disampaikan

"Manipulation is unacceptable, an illegitimate attempt to alter decisions for hidden and spurious interests, and must be excluded from EIA. Manipulation may take place inside or outside $E I A$, from the beginning of the conception of a project. Another possibility is to 
Jurnal Pembangunan Hukum Indonesia

Volume 1, Nomor 3, Tahun 2019
Program Studi Magister Ilmu Hukum Fakultas Hukum Universitas Diponegoro establish an independent auditing in EIA and decision-making processes, but there is no real guarantee of independence in any stakeholder ..." (Enríquez-de-Salamanca, 2018).

Dalam kajian ini, bermaksud lebih jauh, untuk melihat potensi bias dan manipulasi secara empiris, dan terutama dalam konteks penilaian Amdal yang sering dikaitkan dengan independensi. Sementara itu, Cashmore dan Richardson menyampaikan:

"There is no possibility of creating power-free EA processes, where issues of power are handled in formal political processes. EA practitioners, stakeholders and researchers are inescapably enmeshed in power relations" (Cashmore, \& Richardson, 2013).

Penelitian ini bermaksud lebih jauh, yaitu melihat hubungan kekuasaan yang terjadi dalam kasus nyata.

\section{B. METODE PENELITIAN}

\section{a. Titik Pandang atau Standpoint}

Titik pandang yang dipilih dalam penelitian independensi penilaian Amdal adalah Paradigma Critical Theory sebagai world view yang dipedomani peneliti. Melalui suatu set basic belief dalam paradigma Critical Theory demikian, penelitian diarahkan untuk membongkar norma, nilai dan penerapan penilaian Amdal yang dikatakan independen. Dalam penelitian ini tidak dikenal populasi karena sifat penelitiannya adalah studi kasus. Obyek yang diteliti berupa domain-domain atau situasi sosial tertentu yang meliputi tempat, pelaku, dan kegiatan (Suteki, \& Taufani, 2018). Domain tersebut terdiri dari pihak negara, korporasi, dan masyarakat sipil, serta para pakar yang relevan. Key-informan, adalah informan yang jumlahnya tidak ditentukan secara limitatif melainkan mengikuti prinsip snowball.

\section{b. Paradigma}

Paradigma sebagai basic belief dalam penelitian ini adalah Paradigma Critical Theory et.al. (Guba \& Lincoln, 2011). Dalam paradigma critical theory et.al hukum dipahami secara virtual atau historis, selain itu terdapat kesadaran yang tidak benar atau dengan kata lain, disadari secara salah (law as false consciousness or as falsely realised). Pada saat bersamaan hukum menjadi instrumen hegemoni yang cenderung dominan, diskriminatif dan eksploitatif. Sebagai konsekuensi, setiap saat hukum semestinya terbuka bagi kritik, revisi, dan transformasi, guna menuju emansipasi (Indarti, 2010).

\section{Strategi Penelitian}

Penelitian ini menggunakan perspektif sociolegal. Kata "Legal", sesungguhnya terkait dengan studi ilmu hukum yang selama ini banyak dikembangkan dalam pendidikan-pendidikan hukum, terutama mengkaji norma, asas, prinsip, doktrin, interpretasi, dan nalar hukum (legal reasoning). Sedangkan kata "sosio" merupakan pendekatan ilmu non-hukum, baik yang terkait dengan sosiologi hukum, antropologi hukum, budaya hukum, politik hukum, atau sejumlah pendekatan yang menjadikan hukum sebagai obyek kajiannya. Dengan penjelasan demikian, maka bolehlah dinyatakan, "sosio" dalam studi sosio-legal merupakan penelitian sosial tentang 
Jurnal Pembangunan Hukum Indonesia

Volume 1, Nomor 3, Tahun 2019
Program Studi Magister Ilmu Hukum Fakultas Hukum Universitas Diponegoro hukum (Wiratraman, 2016). Karenanya, studi sosiolegal tidaklah semata penelitian sosial tentang hukum, melainkan kombinasi keduanya, studi hukum (legal research) dan studi tentang hukum (social studies of law). Kombinasi yang demikianlah berkarakterkan studi sosio-legal sebagai studi interdisipliner (Wiratraman, 2016). Dalam mempelajari independensi penilaian Amdal, dengan demikian, studi ini bukan sekedar upaya mengembangkan doktrin hukum. Analisa hukum penting, tetapi dalam kasus ini digunakan pemahaman lebih komprehensif masalah hukum dan aplikasinya.

\section{HASIL DAN PEMBAHASAN}

a. Arti Penting Penilaian Amdal perlu dilakukan secara independen (Studi kasus di

\section{Pegunungan Kendeng Utara)}

Pegunungan Kendeng Utara adalah ekosistem pegunungan kapur yang membentang dari di Jawa Tengah hingga Jawa Timur (Tim Pelaksana KLHS Pegunungan Kendeng, 2017a). Sesuai Gambar 1, secara astronomis pegunungan tersebut terletak pada koordinat batas Barat $110^{\circ} 47^{\prime} 25^{\prime \prime}$ BT, batas Timur $112^{\circ} 26^{\prime}$ 42" BT, batas Utara $6^{\circ} 38^{\prime} 34^{\prime \prime}$ LS, batas Selatan $7^{\circ} 10^{\prime} 16^{\prime \prime}$ LS, yang mencakup luas

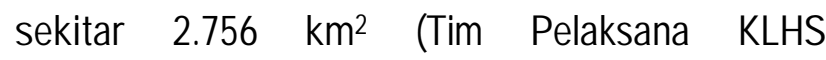
Pegunungan Kendeng, 2017a).
Secara umum Karst memiliki fungsi strategis sebagai penyimpan cadangan air terbesar di bawah permukaan (Wacana, et al., 2014). Karst memiliki fungsi kehidupan yang didasarkan pada fungsi simpanan dan sumber air, fungsi ekologis jasa lingkungan, fungsi penyerap karbon dioksida sebagai bagian proses karstifikasi, dan pengembangan ilmu pengetahuan (Jauhari, 2017). Fungsi karst di Pulau Jawa merupakan ruang hidup (Rodhial Falah, Chandra, \& Wacana, 2017). Di Pulau Jawa, lebih dari 11,2 Juta jiwa tinggal di dalam kawasan batugamping, menunjukkan keterkaitan langsung antara kawasan batugamping dengan kehidupan manusia. Selain sebagai wilayah pemukiman penduduk, kawasan karst dimanfaatkan untuk aneka aktifitas pendukung kehidupan seperti pertanian, perkebunan, peternakan, hutan produksi serta aktivitas yang seharusnya tidak boleh dilakukan di kawasan karst, yaitu pertambangan, baik skala minor (tambang rakyat) maupun skala mayor untuk industri besar (Rodhial Falah, Chandra, \& Wacana, 2017). Lima puluh lima persen Industri Semen di Indonesia berada di Pulau Jawa di wilayah Ekosistem Esensial Karst, yang menjadi penyimpan cadangan air di masa yang akan datang (Masyarakat Speleologi Indonesia, 2016). 


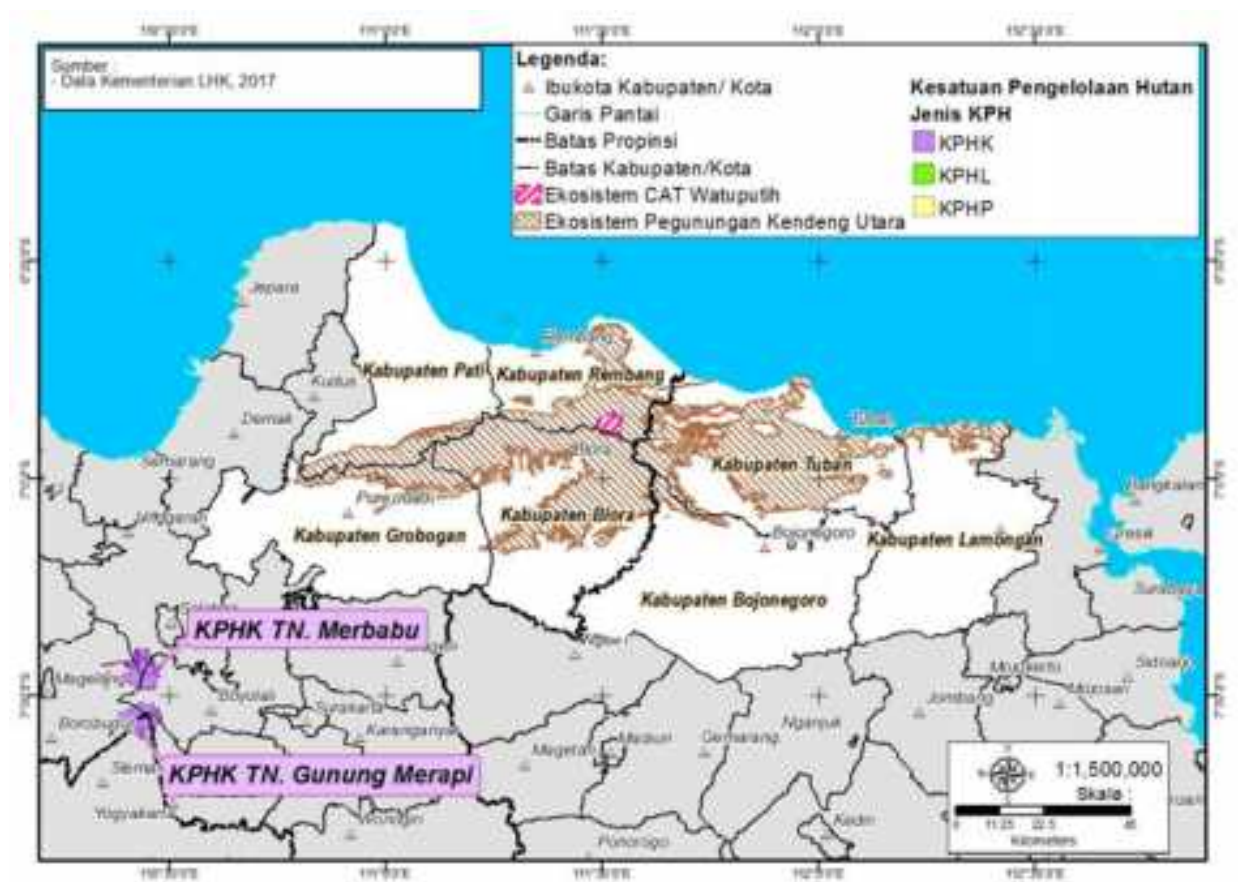

Gambar 1 : Ekosistem Pegunungan Kendeng Utara dalam satu kesatuan tidak terpisahkan (Tim Pelaksana KLHS Pegunungan Kendeng, 2017a).

Secara yurisdiksi teritorial, Pegunungan Kendeng Utara masuk dalam wilayah administratif Kabupaten Grobogan seluas 20.680,8 hektar, Kabupaten Pati seluas 88.964,8 hektar, termasuk di Kecamatan Sukolilo, Kayen, dan Tambakromo, Kabupaten Rembang seluas 39.875,4 hektar, termasuk di Kecamatan Gunem dan Kecamatan Bulu. Kabupaten Blora seluas 19.714,2 hektar. Sedangkan di Jawa Timur, Pegunungan Kendeng masuk di Kabupaten Lamongan seluas 4.982,3 hektar, Kabupaten Tuban seluas 92.207 hektar, dan Kabupaten Bojonegoro seluas 9.175,6 hektar, atau 5,24 persen (Tim Pelaksana KLHS Pegunungan Kendeng, 2017a).

Sebelum masuk ke konteks Amdal, dari konteks historis mengenai kebijakan karst, bahwa, baik pemerintahan orde lama (1950-1966) dan pemerintahan orde baru (1967-1998), ekosistem karst lebih dilekatkan dalam strategi pembangunan ekonomi. Pada pemerintahan Soekarno, dapat di identifikasi melalui pembangunan pabrik Semen Gresik di Jawa Timur yang diresmikan oleh Soekarno pada 7 Agustus 1957 (PT Semen Indonesia (Persero) Tbk, 2013), pembangunan pabrik Semen Tonasa yang mengeksploitasi Karst Pangkep di Sulawesi Selatan, dan mulai beroperasi sejak 2 November 1968, serta menasionalisasi perusahaan semen milik Hindia-Belanda yang merupakan pabrik semen pertama di Indonesia sejak pemerintahan kolonial, yang sekarang menjadi Semen Padang pada 5 Juli 1958 (NewsRoom, 2015).

Pada pemerintahan Soeharto, dalam Rencana Pembangunan Lima Tahun (Repelita) I tahun 19691974, industri semen telah dijadikan sebagai industri prioritas. Disampaikan bahwa Pemerintah Indonesia merencanakan melakukan efisiensi di tiga pabrik 
Jurnal Pembangunan Hukum Indonesia

Volume 1, Nomor 3, Tahun 2019
Program Studi Magister Ilmu Hukum Fakultas Hukum Universitas Diponegoro semen (Gresik, Tonasa-Pangkep, dan Padang), dan akan mempersiapkan lokasi pabrik semen dengan kapasitas 400.000 ton/tahun di Cibinong, Jawa Barat. Hal menariknya, bahwa dalam Repelita I telah merencanakan proyek pendirian pabrik semen yang lokasinya belum difinalkan, namun menyampaikan identifikasi kemungkinan lokasi-lokasi yaitu: Bohorok di Sumatera Utara, Aceh, Klaten dan Pamotan (Rembang) di Jawa Tengah, ataupun Cibadak di Jawa Barat. Sejak Repelita I telah menjadikan industri semen sebagai industri prioritas, kemudian secara konsisten dilanjutkan dalam Repelita selanjutnya hingga keruntuhan orde baru.

Cara pandang berbeda terhadap karst, yakni dalam wujud kebijakan perlindungan, baru lahir pertama kalinya setelah masa keruntuhan pemerintahan orde baru, tepatnya pada tahun 1999 lewat Keputusan Menteri Pertambangan dan Energi Nomor : 1518 K/20/MPE/1999 Tentang Pengelolaan Kawasan Kars. Kebijakan tersebut mengalami perubahan lewat Keputusan Menteri Energi dan Sumber Daya Mineral Nomor : 1456 K/20/MEM/2000 Tentang Pengelolaan Kawasan Kars (Kepmen Karst 2000). Secara normatif, Kepmen Karst 2000 memberikan kesulitan tertentu, yaitu soal klasifikasi kawasan karst menjadi 3 kelas berbeda. Klasifikasi berdasarkan kelas karst ini pada dasarnya menentukan mana kawasan karst yang tidak boleh dan mana yang boleh untuk ditambang (Suhendar, 2015). Aturan dan penetapan yang demikian dinilai telah menimbulkan ambiguitas, ketidakpastian, dan kesulitan bagi rencana pembangunan.
Ketidakjelasan penentuan kelas nyata menjadi batu sandungan bagi rencana pertambangan dan pendirian pabrik semen, yaitu dalam rencana oleh SMGR di Pegunungan Kendeng Utara, tepatnya di Kecamatan Sukolilo bagian dari wilayah administratif Kabupaten Pati, Jawa Tengah pada sekitar tahun 2005-2011. Realitas kasus SMGR di Sukolilo, menjadi bahan refleksi penting untuk perubahan terhadap aturan-aturan normatif yang menjadi batu sandungan bagi investasi. Batu sandungan tersebut berupa aturan mengenai karst (kaitannya dengan tata ruang), aturan mengenai Amdal (kaitannya dengan syarat izin usaha), dan aturan mengenai pertambangan (kaitannya dengan izin pertambangan eksplorasi).

Untuk membantu Daerah dalam penataan ruang berkenaan dengan pemanfaatan kawasan karst, diterbitkan Peraturan Menteri ESDM Nomor 17 Tahun 2012 tentang Pedoman Penetapan Kawasan Bentang Alam Karst (Permen 17/2012) yang menggantikan Kepmen Karst 2000. Permen 17/2012 berisi pedoman penetapan kawasan bentang alam karst dalam rangka mewadahi substansi yang dibutuhkan untuk penyusunan tata ruang (Suhendar, 2015). Perbedaan signifikan antara Kepmen ESDM Karst 2000 dengan Permen 17/2012 adalah, bahwa dalam Permen 17/2012 telah menghapus rintangan yang ada, berupa klasifikasi kelas karst.

Permen 17/2012 turut mencabut 3 Penetapan Kawasan Karst, termasuk mencabut Penetapan Kawasan Karst Sukolilo yang masuk dalam wilayah Pegunungan Kendeng Utara. Walaupun Kawasan 
Jurnal Pembangunan Hukum Indonesia

Volume 1, Nomor 3, Tahun 2019

Bentang Alam Karst (KBAK) ditetapkan kembali pada tahun 2014, dalam penetapan yang baru terdapat pengurangan luas kawasan karst dari yang sebelumnya pernah ditetapkan. Pengurangan terjadi terhadap Kawasan Karst di Gombong yang semula seluas 48,94 $\mathrm{Km}^{2}$ menjadi tinggal seluas $40,89 \mathrm{Km}^{2}$ (Kepmen ESDM Nomor 3873 K/40/MEM/2014); Kawasan Karst Gunung Sewu dan Pacitan Timur yang semula seluas $1468,102 \mathrm{Km}^{2}$ menjadi tinggal seluas 1100,17 Km² (Kepmen ESDM Nomor 3045 K/40/MEM/2014); dan Kawasan Karst Sukolilo semula seluas total 194,72 Km² (Pati seluas 118,02 $\mathrm{Km}^{2}$; Grobogan seluas $72,17 \mathrm{Km}^{2}$; dan Blora seluas 4,53 $\mathrm{Km}^{2}$ ) kemudian ditetapkan dengan jumlah yang meluas yaitu seluas 200,79 $\mathrm{Km}^{2}$ (Pati seluas 71,80 $\mathrm{Km}^{2}$; Grobogan seluas $112,20 \mathrm{Km}^{2}$; dan Blora seluas $16,79 \mathrm{Km}^{2}$ ), kendati luasan total bertambah, untuk daerah Kabupaten Pati terjadi penyempitan luasan seluas 46,22 Km² (Kepmen ESDM Nomor 2641 K/40/MEM/2014).

Mengenai aturan tentang Amdal, refleksi kasus SMGR di Sukolilo dapat dilihat dalam Risalah Sidang pembahasan RUU Pengelolaan Lingkungan Hidup tahun 2009. Disana, pembahasan mengenai Amdal berulang kali berefleksi pada kasus Sukolilo berkaitan Amdal, ialah mengenai dua isu besar Amdal yang hendak dijawab, yaitu mengenai kualitas Amdal dan kualitas penilaian atau pengambilan keputusannya agar tidak dimasuki unsur politik atau kepentingan pejabat publik dan aktor kapital (DPR RI, 2009). Salah satunya dimana Sonny Keraf, menyampaikan:
Program Studi Magister Ilmu Hukum Fakultas Hukum Universitas Diponegoro
"Tapi kalau misalnya ada penolakan, apalagi penolakan itu cukup luas pada beberapa kasus misalnya, saya menghadapi di Pati... mengenai Semen Gresik penolakan luar biasa, terjadi silang pendapat antara dua atau tiga universitas besar dan seterusnya, disini harus sudah menjadi perhatian pengambil keputusan ini (hasil penilaian Amdal) bahwa dia tidak bisa menyetujui begitu saja dokumen ini karena ada tanggapan publik yang luar biasa" (DPR RI, 2009).

Dari sana, terbitlah UU 32/2009 menggantikan UU 23/1997, dan selanjutnya terbit aturan pelaksana mengenai Amdal yaitu PP 27/2012 menggantikan PP 27/1999. Dalam UU 32/2009, Amdal memiliki keterkaitan erat dengan pola ruang dalam aturan tata ruang.

Apabila pembahasan di legislatif diperhatikan, konsepsi seputar Amdal, terutama berkaitan dengan independensi penilaian Amdal dan tim pakar independen, lebih tampak seperti pembahasan konseptual yang tidak tuntas. Konsepsinya berujung pada generalisasi yang tidak koheren dengan maksud awalnya. Generalisasi permasalahan justru dikaitkan dengan sanksi pidana dan rekrutmen yang baik, yang ketika dicermati sama sekali tidak memiliki konsekuensi logis dengan pembatasan potensi kepentingan politis dan kepentingan partikular lainnya dari pemilik kewenangan atributif. $\mathrm{Hal}$ demikian, karena walaupun penilaian dimandatkan kepada Komisi Penilai Amdal (KPA), namun mandat itu diberikan tanpa adanya pembatasan demi menghilangkan peluang masuknya kepentingan partikular dan politis dari pemilik kewenangan atributif. Sementara itu, sanksi pidana dalam UU 
Jurnal Pembangunan Hukum Indonesia

Volume 1, Nomor 3, Tahun 2019
Program Studi Magister Ilmu Hukum Fakultas Hukum Universitas Diponegoro
32/2009 tidak satupun yang memiliki koherensi dengan maksud awal yaitu menghilangkan kepentingan partikular dari pejabat penerbit izin.

Mengenai independensi penilaian oleh KPA (khususnya tim pakar independen) menjadi klausul yang tidak jelas, karena tidak dibahas secara khusus dan mendetail. Yang ada hanya semacam pemolesan dari konsep lama, yang tidak memiliki kejelasan. Hal demikian tentu saja memberi peluang untuk digunakan sebagai alat justifikasi normatif terhadap independensi, objektivitas dan kepakaran, dengan memanfaatkan dikotomi harfiah dan skalar antara kata tergantung/menjadi bagian (dependence) dengan tidak bergantung/terpisah (independent), untuk menutup-nutupi peran kekuasaan seperti disampaikan Nedelsky dan Friedman. Karena itu, independensi penilaian Amdal yang semula dimaksudkan sebagai upaya menghilangkan masuknya kepentingan politik dan kepentingan partikular lainnya dari pejabat pemberi izin lingkungan, juga seperti kata Nedelsky yaitu sebatas "mitos" dan "ilusi" belaka.

Masuk ke tinjauan empiris, bahwa dinamika pelaksanaan Amdal kembali diperhadapkan ke warga dan ekosistem di Pegunungan Kendeng Utara, yaitu lewat rencana INTP pada tahun 2011 di Kecamatan Kayen dan Kecamatan Tambakromo, Kabupaten Pati. Pada 2014 Rapat penilaian Amdal meloloskan Amdal INTP yang berujung pada terbitknya Izin Lingkungan oleh Bupati Pati. Di belahan Pegunungan Kendeng lainnya, setelah gagal di Sukolilo, pada sekitar tahun 2011-2012, SMGR secara cepat mengantongi berbagai persyaratan perizinan untuk mendirikan industri di Kecamatan Gunem dan Kecamatan Bulu, Kabupaten Rembang. Pada 2012, telah terbit Izin Lingkungan bagi SMGR dari Gubernur Jawa Tengah.

Baik Izin Lingkungan INTP maupun SMGR, telah digugat oleh warga ke Peradilan Tata Usaha Negara (PTUN). Dalam sengketa dengan INTP, warga menang di tingkat pertama, namun menelan kekalahan pada tingkat banding di Pengadilan Tinggi dan kasasi di Mahkamah Agung. Dalam putusannya, pengadilan tinggi dan Mahkamah Agung menggunakan argumen yang sangat normatif dan prosedural. Sementara dalam sengketa izin SMGR, warga kalah di tingkat pertama dan tingkat banding juga dengan argumen normatif dan prosedural, namun pada tingkat peninjauan kembali, Mahkamah Agung menggunakan argumen normatif, prosedural dan substantif memutuskan untuk membatalkan izin lingkungan, serta memerintahkan Gubernur Jawa Tengah mencabut Izin Lingkungan SMGR. Akan tetapi, Gubernur Jawa Tengah justru memerintahkan penyempurnaan Amdal oleh SMGR dan penilaian Amdal SMGR oleh KPA Provinsi Jawa Tengah. Pada 23 Februari 2017, Gubernur Jawa Tengah kembali menerbitkan Izin Lingkungan baru untuk SMGR.

Dari sana, tugas kita adalah untuk menyadari bagaimana perilaku normal seperti itu masuk ke dalam mitos tentang proses kebijakan rasional dan terus-menerus mengancam untuk menghadapi fiksi dengan realitas yang merongrong (Wood, 1998). Dalam kasus di Pati yang melibatkan INTP, 
Jurnal Pembangunan Hukum Indonesia

Volume 1, Nomor 3, Tahun 2019
Program Studi Magister Ilmu Hukum Fakultas Hukum Universitas Diponegoro disampaikan bahwa independensi penilaian Amdal terletak pada tenaga ahli dan Institusi keilmuan yang ada dibelakang pejabat berwenang, disana terdapat klaim bahwa tenaga ahli tersebut telah netral dalam melaksanakan penyelenggaraan penilaian (Purwadi, 2019). Ditambahkan bahwa penilaian Amdal INTP adalah penilaian Amdal terbesar yang pernah dilaksanakan karena mengundang banyak pihak, bahwa hampir semua pejabat provinsi kagum dengan Amdal Pati. Semua hadir termasuk Bapak Bupati, Dandim dan Kapolres hadir (Setyaji, 2019) (Purwadi, 2019).

Dalam masyarakat berisiko, sains, teknologi, atau klaim yang dibuat oleh "para ahli" dan penilaian serta pernyataan yang dihasilkan oleh proses Amdal tidak dipercaya oleh publik atau pembuat keputusan yang menjadi tujuan mereka. Bukti menunjukkan bahwa orang tidak percaya dan sangat skeptis bahwa konsultan yang bekerja untuk pemrakarsa proyek dapat memberikan informasi yang tidak bias (Weston, 2003) (Weston, 2004) (Weston, 2010). Bahwa selain itu, pembuat keputusan seolah dapat bertindak "heroik" (Owens, Rayner, \& Bina, 2004).

Sedangkan dalam penilaian Amdal dalam kasus SMGR di Rembang, klaim heroik dan bias juga tampak seperti konteks Amdal yang telah layak lingkungan dari 12 pakar yang sebagian besar Profesor yang di klaim independen (Suprobo, 2019) (Wiharto, 2019). Bahwa hal yang lebih terasa adalah bias berkaitan dengan analogi yang tampak menyesatkan, semisal analogi surat izin mengemudi (SIM) dengan Izin Lingkungan, daya rusak pertambangan di wilayah cekungan air tanah dengan permukiman yang ada diatas cekungan air tanah, bahkan analogi perbandingan semacam "permaafan" dalam konteks pidana atau "kebijaksanaan" ganti kerugian dalam konteks perdata dengan apa yang dilakukan terhadap putusan Mahkamah Agung yang merupakan perkara Tata Usaha Negara (Wiharto, 2019). Hal demikian ialah tafsir sepihak yang bahkan difasilitasi oleh pihak Pemerintah Provinsi Jawa Tengah.

Dari sana, pada intinya mengenai konteks penilaian Amdal SMGR pada tahun 2017 ialah inisiatif dari Gubernur Jawa Tengah, didasarkan pada tafsir terhadap Putusan Mahkamah Agung, diklaim telah sesuai dengan aturan main (rule of law), diklaim telah dinilai secara independen dan diklaim telah melibatkan pakar keilmuan yang independen. Inisiatif sesat, tafsir sepihak, framing menggunakan analogi yang menyesatkan, bahkan dorongan untuk melihat konteks kasus kesudut yang netral, ternyata telah mengaburkan hubungan kekuasaan yang sebenarnya menampakkan ciri yang tidak ideal. Seperti yang disoroti oleh Unger dalam melakukan kritik terhadap formalisme, dengan menyampaikan "the analogy-mongering must be brought to a halt" (Unger, 1983). Hal-hal demikian tidak lain dalam upaya untuk melakukan pengaturan perilaku (conduct of conduct) dan manajemen peluang (Foucault, 2000) (Death, 2014).

Dalam membentuk perilaku tandingannya, warga di Rembang, Pati, bahkan warga lainnya disekitar Pegunungan Kendeng Utara mendirikan 
Jurnal Pembangunan Hukum Indonesia

Volume 1, Nomor 3, Tahun 2019
Program Studi Magister IImu Hukum Fakultas Hukum Universitas Diponegoro wadah penolakan bersama bernama Jaringan Masyarakat Peduli Pegunungan Kendeng (JM-PPK). Siapapun yang hendak peduli terhadap ibu bumi dan secara khusus terhadap Pegunungan Kendeng Utara dapat berkontribusi terhadap gerakan tanpa membedakan pendidikan, latar belakang, gender, agama ataupun kesukuan. Pembagian peran pun dilakukan dengan kesadaran dan kepedulian yang dibangun secara bersama-sama (Prianto, 2019). Mereka berulang kali menyatakan:

"perjuangan ini tidak akan memberikan uang, tanah ataupun gunung, perjuangan ini adalah perjuangan untuk membuat langit tetap biru, udara tetap bersih, sandang-pangan terpenuhi, dan masa depan anak-cucu dapat dilindungi" (Gunretno, 2019).

Warga melakukan aksi seperti longmarch, aksi cor kaki didepan istana negara, aksi cor kaki di depan kedutaan besar Jerman, aksi tenda, aksi lesungan, aksi menunggu di depan kantor gubernur selama sebulan, dan banyak aksi-aksi lainnya. Warga bersama aliansi civil society juga melakukan intervensi terhadap perumusan revisi Peraturan Daerah tentang Rencana Tata Ruang Wilayah (RTRW) Provinsi Jawa Tengah, menyuarakan moratorium perizinan tambang, dan menyuarakan tolak pabrik semen di Pulau Jawa. Pada 2 Agustus 2016, warga berhasil mendorong Presiden Joko Widodo untuk memerintahkan dilakukannya KLHS khusus bagi Pegunungan Kendeng Utara meliputi 7 Kabupaten di 2 Provinsi.

KLHS Pegunungan Kendeng dilaksanakan oleh Kementerian Lingkungan Hidup dan Kehutanan (KLHK) dan Kantor Staf Presiden (KSP) melalui dua tahap, yaitu tahap I meliputi kawasan CAT Watuputih dan sekitarnya di Kabupaten Rembang, dan tahap II meliputi semua wilayah Pegunungan Kendeng Utara. KLHS tahap I mengungkap berbagai hal, salah satunya adalah valuasi ekonomi total biaya yang harus ditanggung setiap tahunnya hingga tahun 2020, apabila terjadi eksploitasi oleh aktivitas penambangan pada ekosistem CAT Watuputih, yaitu sebesar Rp 2.227.916.475.085 per tahun (Tim Pelaksana KLHS Pegunungan Kendeng, 2017a). Sedangkan dalam KLHS tahap II, sebesar: Rp 2.475.627.779.073 per tahun, dengan deviasi 10\% (Tim Pelaksana KLHS Pegunungan Kendeng, 2017b).

Pembahasan empiris kasus di Pegunungan Kendeng Utara, independensi penilaian Amdal, diwarnai oleh upaya pengaturan perilaku (conduct of conduct) dan diwarnai pula dengan "perilaku tandingan", telah semakin menegaskan bahwa penilaian Amdal yang independen ialah ilusi, mitos, dan menutup-nutupi peran kekuasaan. Kenyataannya ialah, bahwa negara (Pemerintah Provinsi Jawa Tengah, Pemerintah Kabupaten Rembang, dan Pemerintah Kabupaten Pati) memainkan peran yang besar dalam memfasilitasi kepentingan perusahaan (SMGR dan INTP), yang berarti berpihak. Dari sana, praktik-praktik seperti memanipulasi pihak-pihak, melindungi ego yang rapuh, bermanuver untuk keuntungan dan kekuasaan, menyebarkan wacana, menetapkan peraturan yang tajam dan mendominasi orang lain, debat metodologi dan seputar kompetensi maupun 
Jurnal Pembangunan Hukum Indonesia

Volume 1, Nomor 3, Tahun 2019

disiplin profesional seakan sudah menjadi kebiasaan yang normal (Wood, 1998).

\section{b. Konsep Ideal Perencanaan berbasis Independensi dalam rangka Perlindungan Lingkungan Hidup}

Landasan ideal ini dibangun diatas pemahaman menggunakan pendekatan relasional yang mengedepankan sentralitas hubungan terhadap nilai-nilai inti kehidupan, dan tidak lantas percaya terhadap mekanisme demokratis yang masih memiliki potensi merusak, daripada menumbuhkan nilai-nilai inti seperti otonomi. Selain itu konsepsi ideal berbasiskan etika kepedulian (ethics of care), dan penggunaan pendekatan yang mengedepankan sentralitas terhadap kebutuhan dari rakyat. Dalam landasan yang demikian, maka pemahaman individualistik liberal harus dihapuskan, dimana hak bersifat konstitutif namun tidak deterministik, hak khususnya hak individual tidak menjadi kartu "truf".

Pembukaan UUD 1945 telah menyampaikan keinginan luhur, yaitu nilai kemerdekaan yang menihilkan penindasan, peri-kemanusiaan, dan perikeadilan. Nilai-nilai ini tentu saja tidak melepaskan (separate) dirinya menjadi berdiri sendiri-sendiri, bahkan terhadap nilai-nilai lain yang belum disebutkan barusan, semisal nilai kedaulatan rakyat, perdamaian abadi, dan nilai lainnya. Nilai-nilai itu non parsial, sama seperti kita memaknai ekologi ataupun (yang disebut Habermas) lebenswelt atau dunia kehidupan, yaitu yang holistik.
Program Studi Magister Ilmu Hukum Fakultas Hukum Universitas Diponegoro

Sedari awal, Amdal dikonstruksi dari cita-cita untuk melindungi lingkungan hidup, dan cita-cita tersebut tidak bisa dilepaskan dari konteks nilai yang telah dijelaskan sebelumnya. Apa yang dirumuskan oleh Habermas mengenai tindakan komunikatif, etika wacana, wacana hukum dan demokrasi deliberatif, dan berperan merumuskan teori perencanaan komunikatif (CPT) adalah berharga, dan dapat menjadi salah satu landasan. Habermas sendiri mengkonsepsikan hukum berada diantara fakta dan norma, dan juga konsepsi komunikatifnya, ialah dalam lingkup yang relasional (Habermas, 1996). Namun konsepsi Habermas dalam kajian ini dirasakan belum mencukupi, dan kemudian konsepsi otonomi relasional Nedelsky, etika kepedulian (ethics of (are), dan penggunaan pendekatan yang mengedepankan sentralitas terhadap kebutuhan dari rakyat, berharga untuk mencukupinya.

Spesifik mengenai konteks perencanaan kebijakan lingkungan hidup. Dalam membicarakan tujuan perencanaan mengenai lingkungan hidup, sudah semestinya mengedepankan sentralitas hubungan terhadap nilai-nilai inti kehidupan. Sentralitas hubungan tersebut yang utama ialah perlindungan lingkungan hidup itu sendiri, kemudian nilai otonomi/kemandirian, kemanusiaan, dan keadilan lingkungan. Sedangkan etika kepedulian, ialah yang memandang penting pengalamanpengalaman para subjek, serta perasaan peduli, yang mana selama ini, selalu ditempatkan sebagai penilaian subjektif dan irasional belaka, yang posisinya seakan lebih rendah daripada penilaian 
Jurnal Pembangunan Hukum Indonesia

Volume 1, Nomor 3, Tahun 2019
Program Studi Magister IImu Hukum Fakultas Hukum Universitas Diponegoro objektif dibawah panji-panji ilmu pengetahuan. Bahwa selain sentralitas terhadap nilai-nilai inti, dan etika kepedulian, perlu ditambahkan pula, bahwa perencanaan lebih baik jika mengedepankan sentralitas terhadap kebutuhan dari rakyat sendiri, yang dinilai tidak hanya secara makro namun dinilai hingga ke hubungan konstruktif terkecil semisal rumah tangga, dan entitas selain manusia seperti tumbuhan, hewan dan bahkan kesatuan ekosistem.

Weston telah menyampaikan bahwa Amdal ada untuk melayani kepentingan kapitalisme (Weston, 2010). Kemudian, Weston menyampaikan: "It is perhaps time that we stop searching for theories to defend it (Amdal; ditambahkan oleh penulis) and start to campaign for something radically different" (Weston, 2010). Transformasi yang radikal sekiranya ialah dengan cara berhenti mengadopsi model dan agenda yang menjadi bagian dari kapitalisme neoliberal atas keinginan mereka menghasilkan akumulasi kapital, dan beralih kepada model perencanaan pembangunan yang mengedepankan sentralitas hubungan nilai-nilai inti, etika kepedulian, dan sentralitas terhadap kebutuhan dari rakyat. Namun, melihat optimisme Nedelsky, dipahami bahwa transformasi sosial dapat direncanakan dan dijalankan secara perlahan, karena perubahan mutlak dan langsung seperti sejarah revolusi diberbagai belahan dunia hampir sulit dilakukan mengingat sejarah kelam dibalik tabirnya, yaitu justru merusak sentralitas hubungan nilai-nilai inti terutama nilai kemanusiaan, bertentangan dengan etika kepedulian, dan dipahami tidak selalu bersandar pada kebutuhan rakyat, melainkan lebih sering bersandar pada kepentingan elit borjuis.

Tujuan dan substansi diberlakukannya instrumen perlindungan lingkungan hidup akan mempertanyakan, bagaimanakah penilaian dampak lingkungan hidup yang independen itu? Pemaknaan dari otonomi atau independen itu sendiri, ialah melebihi dari makna kata netral bahkan imparsial. Hal demikian mensyaratkan penjaminan perlindungan yang menjadi sentralitas hubungan nilai-nilai inti kehidupan, tanggung jawab dan gotongroyong yang menjadi sentralitas hubungan dan turunan dari etika kepedulian, dan kebutuhan rakyat sebagai sentralitas hubungan, dalam artian mengedepankan hal-hal yang benar-benar dibutuhkan oleh masyarakat dan tidak merusak nilainilai inti kehidupan lainnya. Hal demikian kemudian akan menjadi konsepsi dari otonomi atau independensi yang relasional.

Model perencanaan memang diusulkan agar dapat memprioritaskan alternatif selain model perencanaan dominan saat ini seperti penggunaan instrumen Amdal. Namun, menggunakan perencanaan alternatif yang lebih baik, ataupun masih menggunakan model perencanaan dominan seperti Amdal, dirasa perlu menetapkan prasyarat tertentu bagi terlaksananya tujuan dan substansi dari perlindungan lingkungan hidup. Prasyarat tersebut menjadi konsekuensi logis digunakannya pendekatan relasional, dimana pengembangan pendekatan relasional tidak hanya mementingkan sentralitas hubungan terhadap nilai-nilai inti kehidupan. 
Semisal dalam hal masih digunakannya model perencanaan dominan seperti Amdal. Prasyarat bagi otonomi/independensi relasional terhadap Amdal, yaitu dengan terlebih dahulu diberlakukannya penerapan konsep otonomi/independensi relasional dalam pembuatan KLHS, kemudian RTRW/ RPJP/ RPJM/ RZWP-3-K, kemudian barulah Amdal, dan Izin. Pendekatan relasional tidak bisa secara tiba-tiba digunakan pada tahap Amdal, sementara kebijakankebijakan yang mendahuluinya melupakan pendekatan relasional. Bahwa masyarakat harus diikutsertakan dalam perumusan norma hukum yang akan dikenakan kepada mereka sendiri, dalam bahasa Nedelsky ialah "a site of discursive engagement" (Nedelsky, 2011). Bahkan terlebih baik lagi, dimana apa yang dirumuskan ialah organik dari warga masyarakat sendiri yang disusun dari tingkat terkecil yaitu desa dan naik hingga ke tingkat pusat (bottom-up), dan bukan sebaliknya (top-down).

Mekanisme demokratis berpeluang untuk membunuh nilai-nilai inti, karenanya model representatif dan pemungutan suara sebisa mungkin harus dihindari. Prasyarat lainnya ialah, dimana konsep teritori yang masih dalam bayang-bayang dominasi konsep yurisdiksi teritorial dan yurisdiksi personal harus diganti dengan konsep teritori yang lebih berperspektif ekologis, yaitu konsep wilayah berbasiskan ekosistem atau ekoregion.

\section{SIMPULAN}

Independensi penilaian oleh KPA (khususnya tim pakar independen) digunakan sebagai alat justifikasi normatif terhadap independensi, objektivitas dan kepakaran, dengan memanfaatkan dikotomi harfiah dan skalar antara kata tergantung/menjadi bagian (dependence) dengan tidak bergantung/terpisah (independent), untuk menutup-nutupi peran kekuasaan seperti disampaikan Nedelsky dan Friedman. Karena itu, independensi penilaian Amdal juga seperti kata Nedelsky yaitu sebatas "mitos" dan "ilusi" belaka. Hal demikian kemudian dikuatkan oleh telaah empiris kasus di Pegunungan Kendeng Utara yang diwarnai oleh upaya "pengaturan perilaku" (conduct of conduct) dan diwarnai pula dengan "perilaku tandingan" (counter conduct).

Konsep ideal yang dapat diberikan bagi perencanaan dalam rangka perlindungan lingkungan hidup, ialah dalam landasannya, yaitu: Pertama, mengusung pendekatan relasional yang mementingkan sentralitas hubungan terhadap nilainilai inti kehidupan, dan tidak lantas percaya terhadap mekanisme demokratis yang memiliki potensi merusak, daripada menumbuhkan nilai-nilai inti; Kedua, berbasiskan etika kepedulian (ethics of care); dan Ketiga, mengusung konsepsi yang mementingkan sentralitas terhadap hal yang benarbenar menjadi kebutuhan dari rakyat, namun dengan tidak merusak nilai-nilai inti kehidupan. 
Jurnal Pembangunan Hukum Indonesia

Volume 1, Nomor 3, Tahun 2019
Program Studi Magister Ilmu Hukum Fakultas Hukum Universitas Diponegoro

\section{DAFTAR PUSTAKA}

\section{BUKU DAN RISALAH:}

Adams, Guy B., \& Balfour, Danny L. (1998). Unmasking Administrative Evil. Thousand Oaks CA: Sage Publications.

Ardianto, Hendra T. (2016). Mitos Tambang Untuk Kesejahteraan; Pertarungan Wacana Kesejahteraan Dalam Kebijakan Pertambangan. Yogyakarta: Penerbit PolGov.

Azhary. (1995). Negara Hukum Indonesia. Jakarta: UI-Press.

Death, C. (2014). Mengelola Pembangunan Yang Berkelanjutan; Kemitraan, Protes, dan Kekuasaan di KTT Dunia. (Dariyatno, Penerj.) Yogyakarta: Pustaka Pelajar.

DPR RI. (2009). Risalah RUU Tentang Pengelolaan Lingkungan Hidup. Jakarta: Tidak di Publikasikan.

Foucault, M. (1998). The Will to Knowledge: The History of Sexuality Vol. 1. (R. Hurley, Trans.) London: Penguin.

Foucault, M. (2007). Security, Teritory, Population: Lectures at the College de France 1975-1978. (M. Senellart, Ed., \& G. Burchell, Trans.) Basingstoke: Palgrave Macmillan.

Habermas, J. (1996). Between Facts and Norms; Contributions to a Discourse Theory of Law and Democracy. (W. Rehg, Trans.) Cambridge, Massachusetts: The MIT Press.

Hendrapati, M. (2014). Prinsip-Prinsip Hukum Internasional Mengenai Yurisdiksi dan
Tanggung Jawab Negara. (Kadarudin, Ed.) Makassar: Pustaka Pena Press Makassar.

Hill, M. (2005). The Policy Process. 4th edn. London: Pearson Longman.

Indarti, E. (2010). Diskresi dan Paradigma: Suatu Telaah Filsafat Hukum. Semarang: Badan Penerbit Universitas Diponegoro.

Indroharto. (2000). Usaha Memahami UndangUndang Tentang Peradilan Tata Usaha Negara; Buku I Beberapa Pengertian Dasar Hukum Tata Usaha Negara Ed. Rev., Cet. 4. Jakarta: Pustaka Sinar Harapan.

Kamarullah. (2013). Keputusan Tata Usaha Negara

Yang Merupakan Perbuatan Hukum Perdata;

Karakteristik dan Problematika Penanganan

Sengketanya. Pontianak: UNTAN Press.

Kartodihadjo, H. (2017). Di Balik Krisis Ekosistem: Pemikiran Tentang Lingkungan Hidup dan Kehutanan. Jakarta: LP3ES.

Masyarakat Speleologi Indonesia. (2016). Tinjauan Ancaman Kelangsungan dan Daya Dukung Ekosistem Esensial Karst Gombong oleh Rencana Pendirian Pabrik Semen. Bogor: Indonesian Speleological Society (ISS).

Montesquieu. (2015). The Spirit of Laws. (M. K. Anam, Trans.) Bandung: Nusamedia.

Nedelsky, J. (2011). Law's relations : a relational theory of self, autonomy, and law. New York: Oxford University Press.

Ridwan HR. (2013). Hukum Administrasi Negara. Jakarta: PT Raja Grafindo Persada. 
Jurnal Pembangunan Hukum Indonesia

Volume 1, Nomor 3, Tahun 2019

Ritzer, G. (2014). Teori Sosiologi; Dari Sosiologi Klasik Sampai Perkembangan Terakhir Posmodern edisi kedelapan (Terj dari Eight Edition Sociological Theory oleh Pustaka Pelajar). Yogyakarta: Pustaka Pelajar.

Sager, T. (2013). Reviving Critical Planning Theory;

Dealing with pressure, neo-liberalism, and responsibility in communicative planning. London: Routledge.

Suteki, \& Taufani, Galang. (2018). Metodologi Penelitian Hukum: Filsafat, Teori dan Praktik. Depok: Rajawali Pers.

Tim Pelaksana KLHS Pegunungan Kendeng. (2017a). Kajian Lingkungan Hidup Strategis (KLHS) Kebijakan Pemanfaatan dan Pengelolaan Pegunungan Kendeng yang Berkelanjutan Tahap I; Kawasan Cekungan Air Tanah (CAT) Watuputih \& Sekitarnya, Kabupaten Rembang. Jakarta: Kementerian Lingkungan Hidup dan Kehutanan dan Kantor Staf Presiden.

Tim Pelaksana KLHS Pegunungan Kendeng. (2017b). Kajian Lingkungan Hidup Strategis (KLHS) Kebijakan Pemanfaatan dan Pengelolaan Pegunungan Kendeng yang Berkelanjutan Tahap II. Jakarta: Kementerian Lingkungan Hidup dan Kehutanan dan Kantor Staf Presiden.

\section{ARTIKEL J URNAL:}

Amalia, Wisda., Samekto, Adji., \& Prihatin, Eko Sabar. (2016). Perlindungan Hukum Kawasan
Program Studi Magister Ilmu Hukum Fakultas Hukum Universitas Diponegoro

Karst Terhadap Kegiatan Pertambangan Kaitannya Dengan Pengelolaan Lingkungan (Studi Kasus Penambangan Batu Gamping Di Kawasan Karst Gombong Selatan, Kebumen, Jawa Tengah). LAW REFORM, Vol. 12, (No. 1), pp.132-144.

Bartlett, Robert V., \& Kurian, Priya. (1999). The Theory of Environmental Impact Assessment: Implicit models of policy making. Policy \& Politics, Vol. 27, (No. 4), pp. 415-433.

Caldwell, Lynton. K. (1988). Environmental Impact Analysis (EIA): Origins, Evolution, and Future Directions. Impact Assessment, Vol. 6, (No. 34), pp. 75-83.

Cashmore, Matthew., \& Richardson, Tim. (2013). Power and environmental assessment: Introduction to the special issue. Environmental Impact Assessment Review, Vol. 39, pp. 1-4.

Ciptaningrum, Yurike I. R., Atikah, Warah., \& Fadhilah, Nurul L. (2017). Peran Serta Masyarakat dalam Proses Penyusunan Analisis Mengenai Dampak Lingkungan Hidup. e-J ournal Lentera Hukum, Vol. 4, (Issue 1), pp. 61-78.

Coffee, A. (2013). Mary Wollstonecraft, Freedom and the Enduring Power of Social Domination. European J ournal of Political Theory, Vol. 12, (Issue. 2), pp. 116-135.

Coffee, A. (2014 Forthcoming). Freedom as Independence: Mary Wollstonecraft and the Grand Blessing of Life. Hypatia A Journal of 
Feminist Philosophy, Vol. 29, (Issue. 4), pp. Nugroho, W. (2018). INTERACTIONS BETWEEN 908-924.

Enríquez-de-Salamanca, Á. (2018). Stakeholders' manipulation of Environmental Impact Assessment. Environmental Impact Assessment Review, Vol. 68, pp. 10-18.

Friedman, M. (2013, Spring). Relational Autonomy and Individuality. The University of Toronto Law J ournal, Vol. 63, (No. 2), pp. 327-341.

Halldenius, L. (2007). The Primacy Of Right; On Triad Of Liberty, Equality And Virtue In Wollstonecrafts Political Thought. British J ournal for the History of Philosophy, Vol. 15, (No. 1), pp. 75-99.

Hunt, A. (1986). The Theory of Critical Legal Studies. Oxford J ournal of Legal Studies, Vol. 6, (No. 1), pp. 1-45.

Jauhari, A. (2017). Fungsi Karst Sebagai Penyangga Kehidupan - Karst Watuputih Rembang. Semarang: tidak dipublikasi.

Kennedy, D. (1979). The Structure of Blackstone's Commentaries. Buffalo Law Review, Vol. 28, (No. 2), pp. 205-382.

Mackay, S. (2019). Third-Wave Neoliberalism in Practice: Engagement, Equity, and Social Welfare in the Halifax Centre Plan. Critical Planning J ournal UCLA, Vol. 24, pp. 116-130.

Mattila, H. (2019). Habermas revisited: Resurrecting the contested roots of communicative. Progress in Planning, Article in press, $x x(x x)$, pp. 1-19.

\section{LEGAL SYSTEMS IN THE JUDICIAL PROCESS OF KENDENG CASE (A CRITICAL ANALYSIS OF ACCESS TO JUSTICE). Diponegoro Law Review, Vol. 3, (No. 1), pp. 15-27.}

Owens, Susan., Rayner, Tim., \& Bina, Olivia. (2004). New Agendas for Appraisal: Reflections on theory, Practice, and Research. Environment and Planning A: Economic and Space, Vol.36, (Issue 11), pp.1943-1959.

Paden, R. (2003). Marxism, Utopianism, and Modern Urban Planning. Utopian Studies, Vol. 14, (No. 1), pp. 82-111.

Plath, D. (2009). International Policy Perspectives on Independence in Old Age. Journal of Aging And Social Policy, Vol. 21, (Issue. 2), pp. 209223.

Purcell, M. (2009). Resisting Neoliberalization: Communicative Planning or CounterHegemonic Movements? Planning Theory, Vol. 8, (Issue. 2), pp. 140-165.

Richardson, T. (2005). Environmental assessment and planning theory: four short stories about power, multiple rationality, and ethics. Environmental Impact Assessment Review, Vol. 25, (Issue. 4), pp. 341-365.

Ruozzi, E. (2017). The Obligation to Undertake an Environmental Assessment in the Jurisprudence of the ICJ: A Principle in Search of Autonomy. European Journal of Risk Regulation, Vol. 8, (Issue. 1), pp. 158-169. 
Jurnal Pembangunan Hukum Indonesia

Volume 1, Nomor 3, Tahun 2019

Suhendar, R. (2015, Maret). Kebijakan Pengelolaan

Kars di Indonesia. Majalah Geomagz, Vol. 5, (No. 1), pp. 18-21.

Tushnet, M. (1981). Legal Scholarship: Its Causes and Cure. Yale Law J ournal, Vol. 90, Article 15, (Issue. 5), pp. 1205-1223.

Unger, R. (1983). The Critical Legal Studies

Movement. Harvard Law Review, Vol. 96, (No.

3), pp. 561-675.

Unger, R. (2013). Deep Freedom; Why the left should abandon equality. J uncture, Vol. 20, (Issue. 2), pp. 93-100.

Weston, J. (2000). EIA, Decision-making Theory and Screening and Scoping in UK Practice. J ournal of Environmental Planning and Management, Vol. 43, (Issue. 2), pp. 185-203.

Weston, J. (2003). Is there a future for EIA? Impact Assessment and Project Appraisal, Vol.21, (No.4), pp.278-280.

Weston, J. (2004). EIA in a risk society. J ournal of Planning and Environmental, Vol.47, (No.2), pp.313-325.

Weston, J. (2010). EIA Theories: All Chinese Whispers and No Critical Theory. J ournal of Environmental Assessment Policy and Management (JEAPM), Vol. 12, (No. 4), pp. 357-374.

Winkler, T. (2011). On the Liberal Moral Project of Planning in South Africa. Urban Forum, Vol. 22, (No. 2), pp. 135-148.

Wood, G. D. (1998). Projects as communities: consultants, knowledge and power. Impact
Program Studi Magister Ilmu Hukum Fakultas Hukum Universitas Diponegoro

Assessment and Project Appraisal, Vol.16, (No.1), pp.54-64.

Yeager, P. C. (1987). Structural Bias in Regulatory Law Enforcement: The Case of the U. S. Environmental Protection Agency. Social Problems J ournal, Vol. 34, (Issue. 4), pp. 330344.

\section{ARTIKEL PROSIDING}

Attamimi, H. (1994). Der Rechtsstaat Republik Indonesia dan Perspektifnya Menurut Pancasila dan UUD 1945. Makalah pada Seminar Sehari dalam Rangka Dies Natalis Universitas 17 Agustus Jakarta ke -42 . Jakarta: diselenggarakan oleh FH Universitas 17 Agustus Jakarta.

Wacana, Petrasa., IIfanianto, Rodhialfalah, Abe., Widjanarko, Sunu., Suryono, Thomas., Chandra, Fredy., Ahmad, Fandi., Fauzi, Imron., Lukiarti, Ming-Ming. (2014). Kajian Potensi Kawasan Karst Kendeng Utara Pegunungan Rembang Madura Kabupaten Rembang, Jawa Tengah. PROSIDING SEMINAR NASIONAL KEBUMIAN KE-7 (hal. 45-58). Yogyakarta: Jurusan Teknik Geologi, Fakultas Teknik, Universitas Gadjah Mada.

Wiratraman, H. (2016). Studi Sosio-Legal Sebagai Studi Interdisipliner. Makalah untuk Pelatihan Sosio-Legal. Jakarta: Fakultas Hukum Universitas Pancasila dan Epistema Institute. 
Jurnal Pembangunan Hukum Indonesia

Volume 1, Nomor 3, Tahun 2019
Program Studi Magister Ilmu Hukum Fakultas Hukum Universitas Diponegoro

\section{ARTIKEL DALAM BUKU:}

Adamian, M. (2008). Environmental (In)justice in Climate Change. In S. Vanderheiden (Eds), Political Theory and Global Climate Change (pp. 67-84). Massachusetts: The MIT Press.

Coffee, A. (2018). Independence as Relational Freedom. In S. Berges, \& A. Siani (Eds.), Women Philosophers on Autonomy; Historical and Contemporary Perspectives, 1st Edition (pp. 94-112). London: Routledge.

Foucault, M. (2000). The Subject Of Power. In J. D. Faubion (eds), Power: Essential Work of Foucault 1954-1984 Vol. 3 (trans. R. Hurley). New York: The New Press.

Foucault, M. (2001). Omnes et Singulatim: Towards a Critique of Political Reason. In J. D. Faubion (Ed.), Power (The Essential Works of Foucault, 1954-1984, Vol. 3) (pp. 298-325). New York, NY: The New Press.

Guba, Egon. G., \& Lincoln, Yvonna. S. (2011). Kontroversi Paradigmatik, Kontradiksi, dan Arus Perpaduan Baru. In Denzin, Norman. K., \& Lincoln, Yvonna. S (Eds.), The Sage Handbook of Qualitative Research 1, Edisi Ketiga (Daryono, Trans.). Yogyakarta: Pustaka Pelajar.

Mackenzie, C. (2016). Mary Wollstonecraft: An Early

Relational Autonomy Theorist? In S. Bergès, \& A. Coffee (Eds.), The Social and Political Philosophy of Mary Wollstonecraft (pp. 67-91). Oxford: Oxford University Press.

\section{SUMBER ONLINE:}

NewsRoom. (2015). Sejarah singkat PT. Semen Padang. Retrieved from https://www.infosumbar.net/berita/beritasumbar/sejarah-singkat-pt-semen-padang/

PT Semen Indonesia (Persero) Tbk. (2013). Ringkasan Kinerja Pengelolaan Lingkungan PT Semen Indonesia (Persero) Tbk. Retrieved fromhttp://proper.menlh.go.id/portal/filebox/DR KPL\%202013\%20SEMEN\%20INDONESIA\%2 0-\%20GRESIK.pdf

Rodhial Falah, A. B., Chandra, Fredy., \& Wacana, Petrasa. (2017). Karst Jawa Sebagai Ruang Hidup dan Ancamannya. Retrieved from http://pustaka.caves.or.id/index.php?p=show_d etail\&id=173\&_ga=2.35333345.1965899947.1 562174655-201603795.1553518222

\section{WAWANCARA}

Purwadi. (2019). Wawancara Penelitian dengan Purwadi, Kepala DLH Kabupaten Pati/Ketua KPA Kabupaten Pati pada 20 Mei 2019.

Setyaji, A. (2019). Wawancara dengan Agus Setyaji, Kepala Bidang Penataan Lingkungan Dinas Lingkungan Hidup Kabupaten Pati/Komisi Penilai Amdal Kabupaten Pati pada 20-21 Mei 2019.

Suprobo, D. (2019). Wawancara Penelitian dengan Dite Suprobo, Dinas Lingkungan Hidup dan Kehutanan Provinsi Jawa Tengah pada 14 Mei 2019. 
Jurnal Pembangunan Hukum Indonesia

Volume 1, Nomor 3, Tahun 2019

Gunretno. (2019, Mei 20). Wawancara Penelitian dengan Gunretno, warga sekitar pegunungan kendeng pada 20 Mei 2019.

Prianto, J. (2019). Wawancara Penelitian dengan Joko Prianto, warga sekitar pegunungan kendang pada 13 Mei 2019.

Wiharto, A. (2019). Wawancara Penelitian dengan Agung Wiharto, Secretary Corporate PT. Semen Indonesia (Persero) Tbk 2012-2019 pada 22 Juli 2019.
Program Studi Magister Ilmu Hukum Fakultas Hukum Universitas Diponegoro 